\title{
An ExPANded ACCOUnting Framework for Sustainable GROWTH: FOCUS ON THE RELATIONSHIP BETWEEN A FOCAL FIRM AND ITS STAKEHOLDERS*
}

\author{
Taeyoung Yoo and Giseok Nam \\ College of Business, Hankuk University of Foreign Studies, Seoul
}

Accepted: May 2015

\begin{abstract}
In contrast to current accounting principles, which have focused on financial information about the reporting entity, this study suggests that attention should be paid to the information about relationships between a focal firm and its stakeholders. That is, we could more accurately assess the sustainability of a firm's profit and growth by considering both its financial outcomes and business relationships. The rationale of the suggestion is that firms which facilitate mutual profitability between themselves and their stakeholders are more likely to achieve cooperative relationships and consequently enjoy better financial performance and sustainable growth than those who pursue their profitability in an exclusive way. This study therefore suggests that principles of accounting should embrace not only the incomes of a firm and its consolidations (subsidiaries, associates and joint arrangements) but also those of its stakeholders, such as suppliers.
\end{abstract}

Key words: principles of accounting, quality of outcomes, quality of information, societal relationships, sustainable growth

JEL: M14, 21, 41

\section{Introduction}

Since the late 1990s, financial scandals in large European and American firms, such as Crédit Lyonnais of France and Enron of the USA, have raised discourses on accounting reforms and suggested consolidation of auditing standards and restructuring of corporate governance systems. The suggestions aim to acquire credible information on firm activities and their outcomes (Carcello \& Neal, 2003; Jensen, 2001; Orin, 2008). The King III, which is the third report on corporate governance in South Africa after the King I (1994) and King II (2002), has emphasised leadership and sustainability to effectively "improve corporate governance standards and thereby reduce the risk of systemic economic crises in the future" (Institute of Directors in South Africa, 2009:8-10). For instance, it was recommended that "the audit committees, which all firms including listed and state-owned companies should establish, have regard to all factors and risks that may impact on the integrity of the integrated report" (Institute of Directors in South Africa, 2009:31-32). In addition, the King III elaborated on ethical issues, such as good corporate citizenship and the impact of strategy on society and the environment (Institute of Directors in South Africa, 2009:19-21). As a widely adopted accounting standard, IFRS 9 Financial Instruments (International Financial Reporting Standards), issued in July 2014, have also focused on accountability and transparency of financial information. Thus current principles of accounting have emphasised ethical behaviours in addition to accountability of financial positions and performances of firm activities.

However, accounting reforms face theoretical constraints as well as practical limitations. According to the agency theory which narrowly defines a firm's performance in terms of financial outcomes for the sake of shareholders, mutual relationships and societal contexts between business partners are not appropriately considered (Bricker \& Chandar, 2000). The narrow definition of financial performance is not likely to change a firm's attitudes that often prioritise its profits to an unlimited extent at the expense of its business partners. In practice, a series of accounting reforms since 2000 are still outcome-oriented (Vagneur \& Peiperl, 2000) and pay little attention to how 
appropriately a firm should provide information on relationships, defined by Mitchell, Agle and Wood (1997) as the mutual dealings or feelings that exist between two parties and denote a sound process for value creation through cooperation, between the focal firm and its stakeholders, defined by Kochan and Rubinstein (2000:369) as those who affect or are affected by a firm's performance and would experience costs if their relationship with the firm terminates, e.g., employees, suppliers, and local merchants. Given that a firm's performance increasingly depends on mutual cooperation between business partners (Freeman, Wicks, \& Parmar, 2004), the outcome orientation has been criticised as a cause of financial crises and could explain the failure to correct the exploitative attitudes of corporations (Czarniawska, 2012; Otley \& Fakiolas, 2000). Thus the outcome-oriented tendency in theory and practice shows limitations for investors to evaluate appropriately whether a firm's current performance would be sustainable in the future.

We emphasise that even though the literature shows that systems of performance evaluation affect the possibility of dysfunctional decision-making and manipulation of the data (Hopwood, 1972; Vagneur \& Peiperl, 2000), current accounting principles still focus on how to evaluate and report the outcomes of a focal firm's activities without paying much attention to the relationships with its business partners. The quality of information on firm activities is related not only to the outcomes of a firm's own activities but also to its relationships with its stakeholders (Hansmann \& Kraakman, 2004). In this sense, the discourses on accounting principles should pay attention to these relationships, which indicate that a firm's profit and growth are generated through mutual interactions between the focal firm and its stakeholders. Despite this reality, current accounting principles do not pay enough attention to the information which helps to evaluate cooperative relationships around a focal firm. Such lack of relationship information in accounting could not constrain a firm's tendency to maximize profit in an unlimited way, which could lead to unstable and opportunistic relationships with business partners and consequently harm not only its future performance but also jeopardise the wider economy.

We therefore propose an expanded accounting framework which provides both the financial information of a focal firm and information about its relationship with its stakeholders. As proxies for the information that helps to evaluate the relationship, business partners' satisfaction level with a focal firm, R\&D expenditure, profitability, and sales growth could be adopted. This framework, regardless of a focal firm's ethical behaviour, would help to promote cooperation and achieve sustainable growth for both the focal firm and its stakeholders. Because disappointing information about business partners would generate undesirable signals about a focal firm in markets, the focal firm would try to avoid these negative consequences. The expanded framework would complement the existing accounting principles, which are based on consequential outcomes of a firm's activities and do not effectively encourage firms to pay attention to the dimension of relationships in business activities. The expanded framework would encourage business activities to incorporate more compassionate societal domains such as cooperative relations between a focal firm and its stakeholders and thus it could function as a fundamental safeguard against a firm's fraudulent behaviour in maintaining profit maximisation at the expense of its business partners. It highlights why we need a relationship concept to harness current accounting principles and how this would facilitate sustainable growth for corporations. In South Korea, for instance, it is concerning that independent suppliers are suffering from very low operating income, while the large car manufacturers reap unprecedented revenues and profitability (Lee, 2013). We expect that the widening gap of profitability between independent suppliers and car manufacturers will wear away their sound relationships for future cooperation and ultimately erode the prosperity of the car manufacturers due to the suppliers having insufficient income for future investment and cooperation.

This study incorporates the stakeholder approach into accounting principles by suggesting that the information about relationships between business partners should be disclosed in a focal firm's accounting report. However, the dimension of relationships should be differentiated from that of ethics for accountability and prosperity. A body of research criticises accounting practices for their neoclassical tendencies and proposes that we should pay attention to the disclosure of ethics and 
negate the obligation which derives from competition and efficiency (Reiter, 1997; Schweiker, 1993; Shearer, 2002). In contrast, our approach argues that sustainability of a firm's performance can be examined through the information on relationships between a focal firm and its stakeholders. It should be noted that we do not suggest that "the for-itself" model? should be replaced by "the for-the-other" one. Instead, we emphasise that the information on "the for-itself" in accounting standards should be balanced with that on "the for-the-other". This is another issue, different from ethical ones. The logic is that the competitiveness of a focal firm, which will guarantee its above normal profit and sustainable growth, is increasingly dependent on its stakeholders' competitiveness and cooperation. We thus suggest that relationship is not an issue of moral obligation, but of mutual cooperation for survival, and therefore the information about a focal firm's stakeholders should be disclosed in the firm's accounting report.

The remainder of the paper is organised as follows: the second section reviews current principles of accounting to improve accountability of a firm's financial information in respect of fraudulent behaviours. It discusses accounting principles, business practices, and related theories in finding gaps in the outcome-oriented framework of accounting. The third section suggests an expanded framework which sheds light on accounting in accordance with the concept of relationships. Finally, the theoretical and practical implications of this study in contrast to the shareholder model, ethical approach, and critical thought are discussed. Concluding remarks follow. Regarding methodology, this study employs a conceptual approach, which provides a theoretical framework for an empirical or quantitative analysis on accounting principles and practices as a basis for future research.

\section{Discourses on accounting practices and reforms}

\subsection{Issues in the current accounting systems}

The discourses on accounting reform have become one of the main topics in academia as well as in industry, due to the global financial crisis of 2008. There have been debates regarding what information financial reporting should provide on asset valuation and off-balance sheet entities (Merino \& Neimark, 1982; Ryan, 2008). Such issues are related to how accountants evaluate corporate assets and the extent to which firms consolidate their off-balance sheet entities and the publication of related outcomes (Arnold, 2009). For instance, the rules of fair value accounting, which are based on the dynamics of market values and consequently allow a firm's value to vary over time, reflect contrasting approaches in understanding accounting practices. Some criticise the fact that the rules are unstable owing to the nature of market dynamics, and that they show tendencies to overestimate or exaggerate the cycles of financial markets, while others advocate the rules as a tool to grasp the whole picture of market values on specific assets (Boyer, 2007).

We also identify intense disputes regarding the scope of information which corporations should provide about their off-balance sheet activities. The criticism is often levelled that information about a firm's activities in its annual reports is so fragmented that the public find it difficult to utilise it (PWC Australia, 2013). The subprime crisis in the USA around 2007, according to Ryan, is attributable to "the opacity of many subprime positions" and "the complex partitioning of the risks" in the balance sheet $(2008: 1606)$. Despite the debates, the current standards about the offbalance sheet activities a firm should report are limited only to their affiliates. However, the scope of relationships that a firm establishes in its business activities is far beyond that of its affiliated firms. Furthermore, some corporations do not consider the effects of their business activities on the macroeconomic environment; they only provide quantitative information regarding microfinancial performances. While an increasing number of companies report how much they have reduced pollutants such as $\mathrm{CO}_{2}$ emission, they are reluctant to inform the public of the possible environmental and macroeconomic risks their business activities could trigger. Very few firms release information on the precautions they take to prevent damage to the environment or how often they re-evaluate previous decisions for possible neglect of current issues. 


\subsection{Business practices in the outcome-oriented principles of accounting}

It is often noted that the ultimate objective of firm activities is to maximise shareholders' interests. Corporations face two options for profit maximisation: to increase revenues or to decrease costs, including capital expenditure. Thus, firms are forced to manipulate value chains: customers exist at the one end of the chain and suppliers at the other. Firms are eager to market themselves to customers, while they want to control the relationships with their suppliers. In order to maximise profits and report desirable information for investors, firms are tempted to exploit customers and suppliers by abusing their superior positions. Faced with the criticism that the exploitation will negatively affect the sustainability of a focal firm's profit and growth, firms adopt employee compensation programs, increase socially responsible expenditures, and report them in corporate annual reports. Nevertheless, the financial statements in annual reports, which consist of balance sheets (statements of financial position), income statements (statements of comprehensive income), cash flow statements and statements of changes in equity, still emphasise the amount of wealth added to the focal firm. This practice indicates that corporate annual reports do not provide enough information related to a focal firm's diverse stakeholders. This information is critical, since it helps to evaluate the current conditions of a focal firm's business partners and consequently predicts the focal firm's future performance which relies on the cooperation of business partners. Thus the lack of relevant information on its business dealings with partners in a focal firm's annual report could adversely affect the quality of market estimations on the focal firm's future performance. However, current business practices and accounting principles continue to focus on the financial information on a focal firm's activities alone, providing little room to properly reflect and evaluate its diverse relationships which corporations should face and manage in their business activities aimed at value creation.

In practice, the neglect of relationships could lead to inappropriate differences in the distribution of wealth between a focal firm and its stakeholders. Since the mid-1990s, we have seen the free flow of capital, which has promoted the principle of shareholder value maximisation in capital markets. In the interests of competition and efficiency, coupled with outcome-oriented accounting practices, firms have increased real earnings management activities (Bartov \& Cohen, 2009:505). This accounting trend illustrates that firms find it increasingly difficult to meet or exceed analysts' expectations of earnings. A focal firm's possible strategic choice to cope with this situation is to maintain a competitive cost structure by squeezing the profits of its business partners. In most cases in which suppliers are often the underdog, a focal firm is more likely to take full advantage of its superior position. Under the current accounting principles, which provide information on the outcomes of a focal firm's business activities without taking into account the relationships between it and its stakeholders, we expect that the target of a focal firm's profits more often than not could be achieved through the focal firm's unfair management of the interests of its stakeholders, such as suppliers and labour providers. As often reported, globally renowned firms, such as Hyundai Motors and NIKE, have been blamed for the issues of suppliers' extremely low levels of profitability (Lee, 2013) and employment of underage workers (Wall Street Journal, 2013).

\subsection{Contrasting theoretical approaches in understanding principles of accounting}

There is a distinction between neoclassical economics and critical thought, such as the concept of political economy, in understanding the principles of accounting. The neoclassical view of accounting is based on agency theory which emphasises the control of agency cost derived from the separation of ownership and control. The neoclassical approach prioritises the role of markets in which information disclosure through accounting systems facilitates efficient allocation of capital and risk. According to the neoclassical approach, accounting is a neutral technique and reduces information asymmetry between managers and investors (Young, 1996). Thus, enhanced transparency helps markets to operate efficiently. However, the neoclassical approach does not consider the possibility that accounting is not neutral or comprehensive and thus enables a firm to maximise its interests in an unlimited way, at the expense of others. 
In contrast, critical thought suggests that evaluation criteria of firm activities are not an automatic result of efficiency enhancement. Instead, it is a product of competition between different social groups and thus affects the distributive results of social wealth (Tinker, Merino, \& Neimark, 1982). This understanding of accounting rejects the notion of objectivity in measuring and reporting performance of corporations. It argues that accounting is a product of partisan behaviour and is influenced by the interests of the social class in power. We thus note that accounting practices have varied according to different societies and times, and that they have often failed to predict crises in financial markets (Bryer, 1993). Critical approaches, such as economic sociology (Zukin \& DiMaggio, 1990) and poststructuralist theory (Miller \& O'Leary, 1987), have pointed out that the principles of accounting are not determined by mechanical calculations. Instead, they suggest that accounting practices should take account of factors such as social embeddedness and the diffuse process of techniques.

These contrasting approaches illustrate different perspectives regarding accounting practices and provide idiosyncratic theoretical backgrounds for accounting reforms. The neoclassical approach helps to establish both calculative and generalisable grounds, although they are often criticised for not considering the institutional or political contexts of different societies. The common characteristics of the neoclassical approach are well-illustrated by the shareholder model for corporate governance. Based on value maximisation rules with market performance as a basic mechanism of evaluation (Fama \& Jensen, 1985), the shareholder model suggests that resource allocation within corporations should be run on behalf of shareholders who are residual risk bearers as well as capital providers (Fama \& Jensen, 1983; Hart \& Moore, 1990). Regarding the criticism that the shareholder model pays little attention to the fact that economic progress and wealth are generated not only by capitalists but also by other stakeholders who provide firm specific investments, Sundaram and Inkpen (2004) argue that the value maximisation proposition should be the objective function that all firms should follow to resolve conflicting interests among various stakeholders.

In contrast, critical approaches suggest the inclusion of various institutional, cultural, and historical contexts of a society in accounting practices. These context-dependent approaches provide theoretical frameworks to explain why increased transparency fails to promote efficient resource allocation in capital markets, as illustrated by the global financial crisis of 2008. This socio-historical appraisal of transparency argues that the practice of reporting financial information merely functions to keep the status quo of interests of the highly-financialised social class (Merino \& Neimark, 1982).

Both approaches - neoclassical economics and critical thought - regard the other side's suggestion as mutually exclusive and incompatible with their own. However, a critical issue in their understanding of accounting is that both of them mainly draw on the outcomes of firm activities, regardless of whether they put emphasis on the micro dimension of corporations or the macro dimension of the political economy. As illustrated in Figure 1, neoclassical economics examines the financial outcomes of firm activities, while critical thought pays more attention to the societal dimension of outcomes, such as the issue of how the outcomes should be allocated. Despite their differences in understanding accounting practices and principles, their outcomeoriented approaches blind them to an important issue: the relationships a focal firm constructs with its business partners. The latter is disregarded when reporting on information on the focal firm's performance and prospects. Given that a firm's activities are closely related to its business partners, the outcome-oriented approaches are not adequate to provide proper information to evaluate a firm's future prospects. We therefore argue for the importance of relationships, which work as an indicator of sound process for value creation, in evaluating a firm's activities and raise the question of how differently we could interpret the scene of firm activities by paying attention to the dimension of process in addition to that of outcome in the accounting system. This question implies that we need to examine the diverse relationships between a focal firm and its stakeholders which existed prior to the outcomes of firm activities and will affect them in the future. We 
propose that if we have proper, adequate information about the relationships between a focal firm and its stakeholders, we could more precisely predict the focal firm's future performance.

Figure 1

Contrasting practices and theoretical backgrounds in accounting

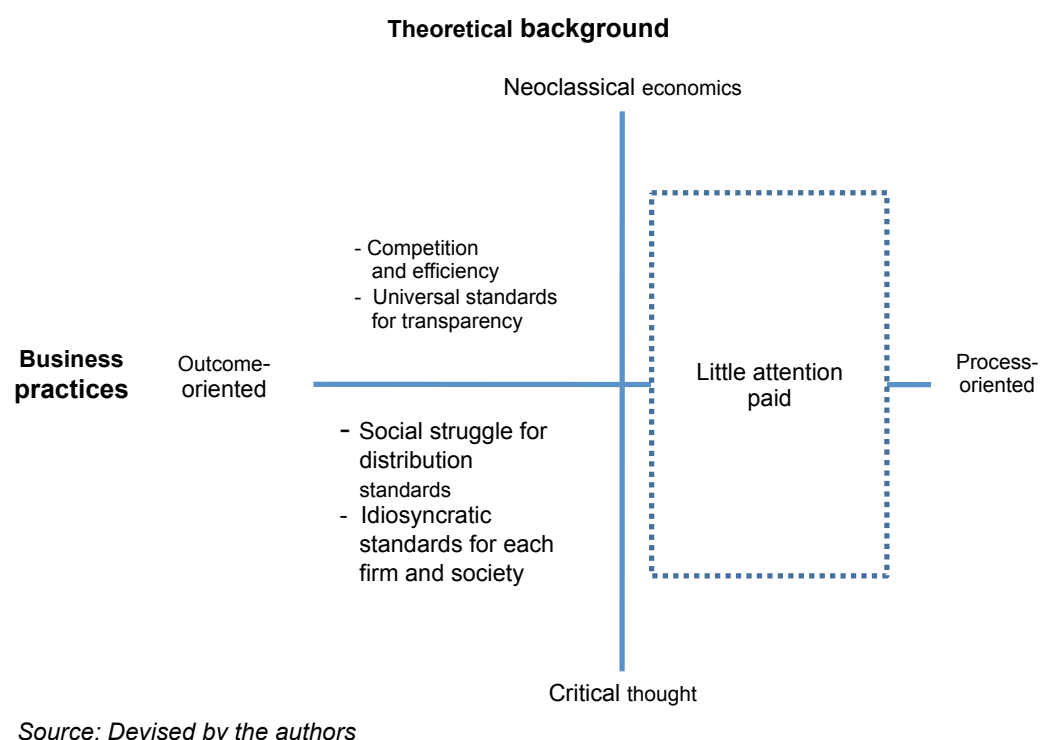

\section{An expanded approach for the relationship dimension of value creation}

The remedies for corporate scandals in the 2000s, illustrated by the King III, have relied on transparency and accountability of corporate information. The new rules have advocated the consolidation of monitoring mechanisms and strengthened penalties on CEOs and CFOs for financial wrong-doings in line with the concept of accounting ethics. However, we have not yet observed effective constraints on a firm's fraudulent behaviours; instead, we have faced more serious financial scandals on a global scale. The IFRS addresses these unsatisfactory phenomena and introduces some corrective measures for inflexible regulation of accounting items, and consequently provides more discretion for accounting agencies and reporting corporations. The conceptual framework of IFRS defines the purpose of accounting as the provision of proper, relevant, accurate financial information for investors' decision-making. It nevertheless could face the criticism that its principle-based rather than rule-based stance could allow relatively more discretion and consequently limit the improvement of the quality of information.

A more fundamental issue relates to the outcome-orientation in the current accounting framework. Since capital markets still emphasise shareholder's value even under the revised accounting rules (Sundaram \& Inkpen, 2004), firms are likely to focus on how to increase their outcomes, leading to disproportionate earning distributions between them and their stakeholders. In some countries, for instance South Korea, the average ROA of car manufacturers is three or four times higher than that of their suppliers (Lee, 2013). The relatively poor attention given to the information on relationships in the practice of accounting could lead the structure of value creation to unlimited levels of competition and drive market attitudes in a specific direction which places little value on cooperation. The unstable business environments caused by the pressure of competition and the relative lack of cooperative motivation, would make it unlikely that the current profit and growth of a firm could be sustained in the future.

As illustrated in Figure 2, to evaluate the sustainability of a firm's profit and growth effectively, we suggest that accounting principles should embrace the interactions between a focal firm and its 
stakeholders, in addition to the firm's current financial performance. The expanded perspective illustrates that the current practices and principles of accounting do not adequately take into account the possibility that a firm's current performance could be a result of unfair management of business partners. This is because they adopt outcome-oriented standpoints regardless of whether they hold neoclassical positions or critical approaches. In the principles which prevail at present, there is little room to balance conflicting interests between market players, owing to the advocacy of efficiency or the competition for distribution. The neoclassical approach, based on transparency and monitoring mechanisms for efficiency, inevitably contributes to the unstable equilibrium between competing groups. This is because it evaluates the success of a focal firm's activities by concentrating on its value maximisation, and paying scant attention to the mutual benefits of diverse parties involved in the business. According to Czarniawska, "contemporary culture is characterized by hostility to closure" (2012:769), which Seaford regards as a result of "our hypermonetized, atomized, and self-destructive culture of the unlimited" (2009:15). On the other hand, the conflicting or inadequately coordinated interests between business partners unavoidably produce merciless struggles for a larger share among them and consequently this promotes opportunistic behaviours in business activities. The political economic understanding of accounting practices implies that "markets promote self-interested behavior, irrespective of its impact on society" (Merino, 2006). Therefore the current principles in accounting, such as IFRS, are not sufficiently helpful for conflict resolution between business partners, even when they intend to improve the quality of corporate information for investors. This study thus challenges the accounting principles in accordance with fair value in IFRS, which obscures the value creation process (Boyer, 2007:779), and ultimately sheds light on social analysis of accounting, highlighting the need for correction of economic determinism (Arnold, 2009).

Figure 2

An expanded framework of accounting

Newly added criteria

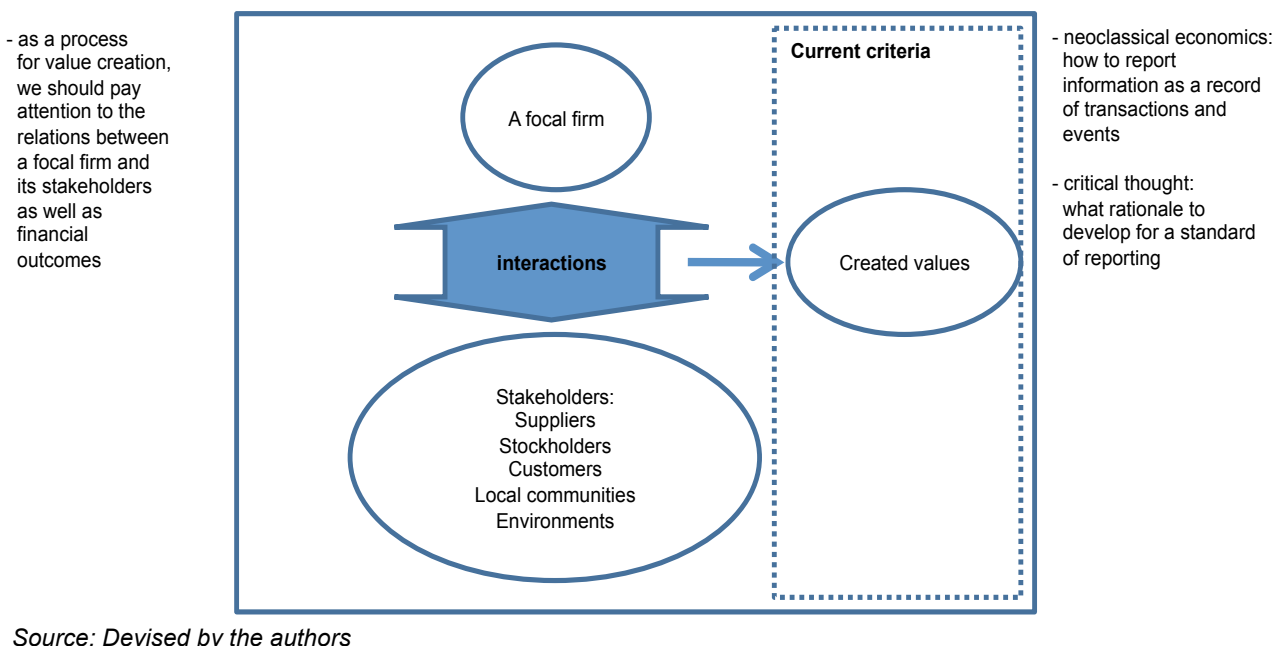

Our suggestion is supported by a couple of economic theories and practical experiences. Firstly, an individual firm's competitiveness increasingly depends on its capability of organising and utilising networks of related and unrelated firms instead of only its own resources and capabilities (Nohria \& Eccles, 1992; Rosenfeld, 1996; Scott, 1991). The network approach emphasises that cooperative behaviour will help firms to exchange their current knowledge and to complement one anothers' competitiveness. For instance, the outcomes of innovation could be more substantive when innovation activities are arranged by systemic cooperation between a focal firm and its diverse stakeholders than on its own. Toyota reports that the virtual inclusion of suppliers into its 
manufacturing and marketing structure helps to promote innovation activities and improve customer satisfaction (Toyota Annual Report, 2008). Innovation cluster (Ozer \& Zhang, 2015), which can be implemented both at corporate (e.g., Toyota and its suppliers) and at regional (e.g., Silicon Valley) levels, also proves the usefulness of cooperation between business partners.

Secondly, the organisational learning approach sheds light on the cooperative relationship between business partners for explorative learning which facilitates new possibilities of competitiveness (March, 1991). The business environments of competition lead to exploitative learning, which encourages firms to stick to old certainties at the expense of future opportunities. As March observes: "tendencies to increase exploitation and reduce exploration make adaptive processes potentially self-destructive" (1991:73). In contrast, mutually beneficial relationships in the process of producing outcomes generate open environments for knowledge exchange and therefore enable firms to accumulate mutual learning. This cooperation will help them to explore long-term investment. Furthermore, the fair relationship in the left dimension of Figure 2 will improve trust between a firm and its stakeholders (Powell, 1996; Sako, 1992) and decrease transaction costs (Osborn \& Hagedoorn, 1997; Williamson, 1985), ultimately facilitating sustainable value creation and growth.

As a business experience, the Toyota case illustrates a knowledge-based economy within the network organisation (Fujimoto, 1999). Sound relationships in the process of production explain how Toyota created its competitive cost structure, represented by the "just-in-time" production system, and established the product differentiation structure, represented by the total manufacturing and quality control system. The competitiveness of Toyota, which relies on its good relationships with suppliers through cooperative partnership, demonstrates the importance of cooperative relationships for competitiveness and sustainable growth. This kind of business relationship could be called "architecture-based comparative advantage" (Fujimoto, 2006:3) or "knowledge factory" (Roth, 1996:32). At the industrial level, the Danish government designed a program to promote corporate cooperation through networks. The networks were arranged to enter new markets, or to develop and produce new products (Gelsing, 1992). We also find the relationship model for sustainable growth in the United States of America. Some states, such as Michigan, Oregon, and Kentucky, have provided incentives in building partnerships and trust among corporations and established regional hubs to enhance the common practice of collaboration (Rosenfeld, 1996). According to a survey, the corporations in the network programs benefitted from mutual learning and services which were not affordable independently. The relationship-based activities strengthen the competitiveness of both participating firms themselves and the industries in which they operate.

The expanded approach in this study emphasises that information on the dynamics of relationships between a focal firm and its stakeholders forms the background to the financial outcomes of business activities and helps to evaluate how sustainable the outcomes of business activities are, in addition to their size. It would be unwise as well as short-sighted to assume that the current financial statement in accounting, which is based on maximisation of return from competition, could help to predict a focal firm's construction of sustainable value creation successfully (Boyer, 2007). Owing to the conflicting characteristics of the relationship between a focal firm and its stakeholders under the framework of value maximisation, the outcome-oriented accounting systems could facilitate opportunistic corporate behaviours and subsequently build up unstable business environments. A conflicting relationship between a focal firm and its stakeholders prevents related firms from maintaining long-term cooperation, a critical resource for value creation. The long-term relationship affects the investment of resources in innovation activities and the trajectory of corporate growth. In this sense, expanded accounting principles, which provide both financial and relational information about a focal firm, could constrain exploitative behaviours between business partners and promote cooperation, eventually consolidating the structure of value creation for the firm. 


\section{Implications of the relationship-based approach to accounting}

\subsection{Theoretical implications}

It needs to be emphasised that our suggestion is not completely opposed to the current accounting principles, but is complementary to them. Our approach highlights the fact that while the current accounting principles intend to provide quality information on corporations for investors, they are not helpful in predicting the sustainability of corporate prosperity which relies on the resolution of conflicts between business partners. We therefore suggest that the information on whether the outcome generation between business partners is mutually satisfactory and beneficial for future cooperation should be included in a focal firm's accounting reports, in addition to the financial information about only the focal firm itself. Our approach illustrates that sustainability of an entity cannot be properly evaluated only by the accounting principles applied in measuring a focal firm's profit or loss. Beyond the financial outcomes of a focal firm's past activities, accounting principles should help to evaluate the status of relationships between business partners behind the outcomes and to predict the focal firm's value creation in the future.

Firstly, the suggestions in this study advance the stakeholder perspective in accounting principles. The stakeholder perspective emphasises that stakeholders, such as employees, suppliers, and local merchants, should have rights to residual claims because they provide a focal firm with human capital as well as physical assets, which necessitates the sharing of firm-specific risks (Kochan \& Rubinstein, 2000). The Saturn case of General Motors (GM) shows how cooperative relationships between the car manufacturer and its suppliers made the Saturn successful on the markets. The stakeholder perspective sheds light on the management of relationships between all constituents for value creation.

Secondly, this study is different from the ethics approach based on moral obligation. We also do not hold that sound relationships should take precedence over profitability and financial consolidation. Instead, to keep them sustainable, a reporting entity in accounting should report the information which indicates how well a focal firm constructs cooperation as a process leading to successful outcomes with its business partners, in addition to its current financial outcomes. In broader terms, the suggestion in this study has similarities with the ethical approach found in the current accounting reforms, but it is more regulation-based, beyond good citizenship behaviour. The ethical approach argues that corporate behaviour should maintain moral obligations (Herremans, Akathaporn, \& McInnes, 1993, Shearer, 2002). The ethical behaviour of corporations will increase their performance through the achievement of social legitimation. The current accounting principles, such as the King reports on corporate governance, i.e., the King I, King II and King III, give the notion of corporate citizenship more credence and concrete expression than ever before, highlighting the unbroken chain that links ethical leadership, company strategy and sustainability (Institute of Directors in South Africa, 2009). However, fraudulent behaviours in accounting are still being detected, despite the consolidation of accounting standards and particular emphasis on ethical behaviours. A survey of accounting students' and professionals' perceptions of earnings management before and after the passage of the Sarbanes-Oxley also indicates that "earnings management [is] more questionable and less ethical than their pre-SOX counterparts" (Grasso, Tilley, \& White, 2009:45).

Faced with an unexpected result, this study states that the outcome-oriented standards of evaluation, which provide little room for information on relationships between business partners, could bolster opportunistic behaviour of corporations and consequently incline them to adopt unethical practices to maximise their profits. Regarding the discord between ethics and outcome orientation in accounting principles, we suggest that ethical behaviour can be secured when the principles of accounting are expanded to accommodate information on relationships. Critically, we do not argue for benevolent decision-making of a focal firm on the basis of moral obligation or social legitimation. On the contrary, the expanded framework in this study proposes that the information on the relationship, which helps to evaluate whether business partners are mutually 
dependent for business activities, will effectively constrain a firm's self-interested activities for its own exclusive gain and consequently facilitate mutual cooperation. The expanded framework thus encourages firms to maximise their profits on the condition that their stakeholders can also be prosperous. The co-prosperity between a focal firm and its stakeholders is not an outcome of the focal firm's moral stance, but of striving for profits that will benefits all stakeholders.

Critical thought such as the political economy of accounting have pointed out that accounting and auditing standards should be understood in the social and historical contexts of capitalism, and that choices of accounting standards reflect the political, economic and social contestations between diverse social groups (Bryer, 1993; Burchell, Clubb, Hopwood, \& Hughes, 1980; Cooper \& Sherer, 1984). As illustrated by the change of accounting standards in the Lancashire cotton mills around the early $20^{\text {th }}$ century, social movements of manufacturers and investors changed the accounting systems (Toms, 2002). While this perspective provides a new accounting framework different from economic and positivist approaches, it still seeks for outcome-oriented solutions in reallocating produced outcomes between competing social groups. The expanded framework in this study, on the other hand, emphasises the relationship dimension in annual reports of a focal firm. While the competing relationships in the critical thought paradigm could correct the profits of a focal firm which come about at the expense of its stakeholders, it does not guarantee a firm's prosperity in the long term. Instead, the prosperity could be more accurately predicted when cooperative relationships are fostered in accordance with the expanded framework proposed in this study.

\subsection{Practical implications}

The relationship between diverse stakeholders is not constituted in the current accounting principles and practices. The outcomes of economic activities of a focal firm and its consolidations (subsidiaries, associates and joint arrangements) mainly appear in the annual report. We therefore suggest that the performances of the focal firm's business partners, such as ROA, R\&D expenditure, and satisfaction level with the focal firm in the case of suppliers, should be reported in the annual report of the focal firm, because they could be proxies that indicate the nature of the relationship between a focal firm and its suppliers. The scope of suppliers, whose performance should be reported in a focal firm's annual report, could be designated as those whose sales consist of more than $5 \%$ of the focal firm's purchase. The $5 \%$ threshold is often used in determining whether an entity is influential in a specific event. For instance, institutional investors that own more than $5 \%$ shares of a firm should be reported in the firm's annual report.

It is the authors' belief that the more profitable a focal firm's business partners are, the more consistent and sustainable their relationships will be. The soundness of the relationship in effect contributes to the sustainability of the focal firm's profit and growth. As an example, car manufacturers' cooperation with their suppliers for R\&D activities and product development becomes critical and indispensable. The firm whose suppliers suffer from very low profitability and growth rates cannot expect any productive cooperation with its business partners. Consequently, to improve a focal firm's survival and prosperity, accounting principles are needed that report the information about conditions of the relationship between a focal firm and its suppliers. One of the possible proxies for the relations could be the performance index of the focal firm's suppliers, as illustrated in Figure 3. In the case of a focal firm's suppliers, their satisfaction level with the focal firm, R\&D expenditure, and profitability and sales growth reported in the focal firm's annual reports will help to predict the sustainability of the focal firm's current performance more accurately. These criteria can also be applied to the performance indices of employees, customers, and local communities of the focal firm. 
Figure 3

An example of expanded accounting framework

Current accounting

Expanded accounting
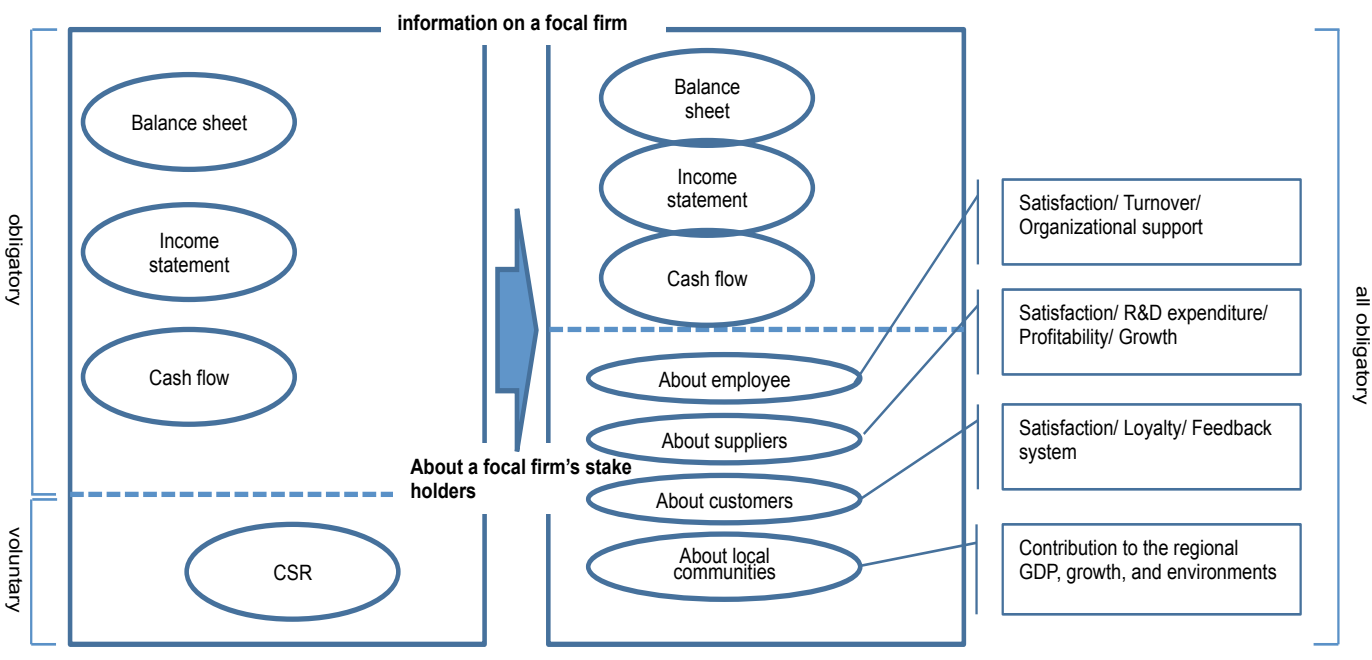

Source: Devised by the authors

More specifically, in the case of a focal firm's suppliers, the relationship-based performance index (RPI) can consist of the following formula:

$\mathrm{RPI}_{\text {supplier }}=\mathrm{S}+\mathrm{Rd}+\mathrm{P}+\mathrm{Sg}$ : S(satisfaction); Rd(R\&D); $\mathrm{P}$ (profitability); $\mathrm{Sg}$ (sales growth)

$\mathrm{S}=\mathrm{S}_{\mathrm{f}}+\mathrm{w}_{1} * \mathrm{~S}_{1}+\ldots+\mathrm{w}_{\mathrm{n}} * \mathrm{~S}_{\mathrm{n}}$ : standardized score of a focal firm's satisfaction level $\left(\mathrm{S}_{\mathrm{f}}\right)$ and weighted average of major suppliers' satisfaction level $\left(\mathrm{w}_{1} * \mathrm{~S}_{1}+\ldots+\mathrm{w}_{\mathrm{n}} * \mathrm{~S}_{\mathrm{n}}\right)$

$\mathrm{Rd}=\mathrm{S}_{\mathrm{f}}+\mathrm{w}_{1} * \mathrm{Rd}_{1}+\ldots+\mathrm{w}_{\mathrm{n}} * \mathrm{Rd}_{\mathrm{n}}$ : standardized score of a focal firm's $\mathrm{R} \& \mathrm{D}$ expenditure $\left(\mathrm{Rd}_{\mathrm{f}}\right)$ and weighted average of major suppliers' $R \& D$ expenditure $\left(w_{1} * R_{1}+\ldots+w_{n} * R_{n}\right)$

$\mathrm{P}=\mathrm{P}_{\mathrm{f}}+\mathrm{w}_{1} * \mathrm{P}_{1}+\ldots+\mathrm{w}_{\mathrm{n}} * \mathrm{P}_{\mathrm{n}}$ : standardized score of a focal firm's profitability $\left(\mathrm{P}_{\mathrm{f}}\right)$ and weighted average of major suppliers' profitability $\left(\mathrm{w}_{1} * \mathrm{P}_{1}+\ldots+\mathrm{w}_{\mathrm{n}} * \mathrm{P}_{\mathrm{n}}\right)$

$\mathrm{Sg}=\mathrm{Sg}_{\mathrm{f}}+\mathrm{w}_{1} * \mathrm{Sg}_{1}+\ldots+\mathrm{w}_{\mathrm{n}} * \mathrm{Sg}_{\mathrm{n}}$ : standardized score of a focal firm's sales growth $\left(\mathrm{Sg}_{\mathrm{f}}\right)$ and weighted average of major suppliers' sales growth $\left(\mathrm{w}_{1} * \mathrm{Sg}_{1}+\ldots+\mathrm{w}_{\mathrm{n}} * \mathrm{Sg}_{\mathrm{n}}\right)$

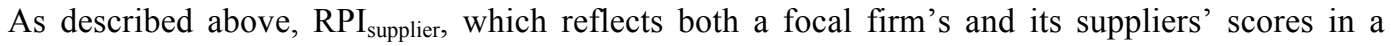
certain year, will help to evaluate the coordination quality of business activities between the two

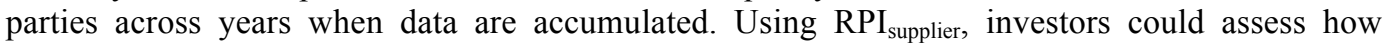
satisfied the suppliers are with their current business with a focal firm and find out whether there is a gap in the earnings trajectory between the two parties. If the gap widens, where the focal firm's score increases while its suppliers' score decreases or stagnates, the business relationship cannot be maintained. This could function as a relationship indicator to predict the sustainability, or lack of it, of a focal firm's current business.

Also, to persuade firms to adopt the relationship-based accounting standards, it does matter who leads the initiative in institutionalising the relationship between a focal firm and its stakeholders in accounting principles. This requires relationship-reorientation. As illustrated by the major Western countries that still remain important players in regulating global business with accounting technologies (Arnold \& Sikka, 2001), nation-states should assume leadership to introduce alternative accounting formats (Yoo \& Jho, 2015; Yoo \& Lee, 2009). The case of the institutionalisation of generally accepted accounting principles (GAAP) in the USA shows how potent a government's coercive policy can be (Carpenter \& Feroz, 2001). In the US case, each regional state's resistance to the pressures for GAAP adoption has failed owing to the wellorganised governmental institutional strategies. This phenomenon illustrates that we should consider institutional and organisational contexts as well as economic efficiency in restructuring accounting systems. 


\section{Conclusion}

Due to the financial scandals and subsequent recession worldwide around the 2000s, more attention has been placed on accounting management and related issues such as monitoring mechanisms. In this study, we have argued that the discourses on accounting practices and reforms were outcome-oriented regardless of whether their suggestions relied on neoclassical or critical approaches. This means that the two approaches are not very different in terms of what is being regulated, even though they do not agree with the issue of how to govern such regulations. For both, the object which should be regulated is the outcome of economic activities. Therefore, they have been concerned with which information should be reported, what monitoring mechanisms should be introduced, and which principles of accounting should be revised, in terms of the outcome of economic activities. However, in contrast to the current discourses, this study suggests an expanded framework of accounting which reports information on the relationship between a focal firm and its stakeholders as an indicator of sustainable value creation, in addition to the financial outcome of the firm's own economic activities. Using the framework, we have argued that annual reports should provide information on the quality of relationships between business partners for the sustainable growth of the focal firm. Cooperative relationships between economic players, avoiding predatory behaviour such as unfair distribution of profits for suppliers, can help to predict more accurately the sustainability of the focal firm's current performance.

\section{Acknowledgement}

*A previous version of the paper was presented at the 2011 European Group for Organization Studies (EGOS), Gothenburg, Sweden. This work was supported by the Basic Science Research Program through the National Research Foundation of Korea (NRF) funded by the Ministry of Education, Science and Technology (NRF-2013S1A3A2053799) and by Hankuk University of Foreign Studies Research Fund of 2015.

\section{References}

ARNOLD, P. 2009. Global financial crisis: The challenge to accounting research. Accounting, Organizations and Society, 34(6):803-809.

ARNOLD, P. \& SIKKA, P. 2001. Globalization and the state-profession relationship: The case of the Bank of Credit and Commerce International. Accounting, Organizations and Society, 26(6):475-499.

BARTOV, E. \& COHEN, D. 2009. The "Numbers Game" in the pre- and post-Sarbanes-Oxley eras. Journal of Accounting, Auditing \& Finance, 24(4):505-534.

BOYER, R. 2007. Assessing the impact of fair value upon financial crisis. Socio-Economic Review, 5(4):779807.

BRICKER, R. \& CHANDAR, N. 2000. Where Berle and Means went wrong: A reassessment of capital market agency and financial reporting. Accounting, Organizations and Society, 25(4):529-554.

BRYER, R.A. 1993. The late nineteenth-century revolution in financial reporting: Accounting for the rise of investor or managerial capitalism? Accounting, Organizations and Society, 18(7/8):649-690.

BURCHELL, S., CLUBB, C., HOPWOOD, A. \& HUGHES, J. 1980. The roles of accounting in organizations and society. Accounting, Organizations and Society, 5(1):5-27.

CARCELLO, J. \& NEAL, T. 2003. Audit committee characteristics and auditor dismissals following "new" going-concern reports. Accounting Review, 78(1):95-117.

CARPENTER, V. \& FEROZ, E. 2001. Institutional theory and accounting rule choice: An analysis of four US state governments' decisions to adopt generally accepted accounting principles. Accounting,

Organizations and Society, 26(7/8):565-596.

COOPER, D. \& SHERER, M. 1984. The value of corporate accounting reports: Arguments for a political economy of accounting. Accounting, Organizations and Society, 9(3/4):207-232.

CZARNIAWSKA, B. 2012. New plots are badly needed in finance: Accounting for the financial crisis of 2007-2010. Accounting, Auditing \& Accountability Journal, 25(5):756-775. 
FAMA, E. \& JENSEN, M. 1983. Separation of ownership and control. Journal of Law and Economics, 26(2):301-325

FAMA, E. \& JENSEN, M. 1985. Organizational forms and investment decisions. Journal of Financial Economics, 14(1):101-119.

FREEMAN, E., WICKS, A. \& PARMAR, B. 2004. Stakeholder theory and "the corporate objective revisited". Organization Science, 15(3):364-369.

FUJIMOTO, T. 1999. The evolution of a manufacturing system at Toyota. New York: Oxford University Press.

FUJIMOTO, T. 2006. Architecture-based comparative advantage in Japan and Asia. In Ohno, K. \& Fujimoto, T. (eds.) Industrialization of developing countries: Analyses by Japanese economists. Tokyo: University of Tokyo:1-10.

GELSING, L.E. 1992. Innovation and the development of industrial networks. In Lundvall, B.-Å. (ed.) National systems of innovation: Towards a theory of innovation and interactive learning. London: Frances Pinter Publishers:116-128.

GRASSO, L., TILLEY, P. \& WHITE, R. 2009. The ethics of earnings management: Perceptions after Sarbanes-Oxley. Management Accounting Quarterly, 11(1):45-69.

HANSMANN, H. \& KRAAKMAN, R. 2004. The basic governance structure. In Kraakman, R., Davies, P., Hansmann, H., Hertig, G., Hopt, K., Kanda, H. \& Rock, E. (eds.) The anatomy of corporate law: A comparative and functional approach. Oxford: Oxford University Press:33-70.

HART, O. \& MOORE, J. 1990. Property rights and the nature of the firm. Journal of Political Economy, 98(6):1119-1158.

HERREMANS, I., AKATHAPORN, P. \& MCINNES, M. 1993. An investigation of corporate social responsibility reputation and economic performance. Accounting, Organizations and Society, 18(7/8): 587-604.

HOPWOOD, A.G. 1972. An empirical study of the role of accounting data in performance evaluation. Journal of Accounting Research, 10(3):156-182.

INSTITUTE OF DIRECTORS IN SOUTH AFRICA. 2009. King code of governance for South Africa. South Africa: Institute of Directors in South Africa.

JENSEN, M. 2001. Value maximization, stakeholder theory, and the corporate objective function. Journal of Applied Corporate Finance, 14(3):8-21.

KOCHAN, T.A. \& RUBINSTEIN, S.A. 2000. Toward a stakeholder theory of the firm: The Saturn partnership. Organization Science, 11(4):367-386.

LEE, H. 2013. The phenomenon and issues in the Korean auto industry. Seoul, S. Korea: Korea Institute for Industrial Economics and Trade.

MARCH, J.G. 1991. Exploration and exploitation in organizational learning. Organization Science, 2(1): 71-87.

MERINO, B.D. 2006. Financial scandals: Another clarion call for education reform: A historical perspective. Issues in Accounting Education, 21(4):363-381.

MERINO, B.D. \& NEIMARK, M.D. 1982. Disclosure regulation and public policy: A sociohistorical appraisal. Journal of Accounting and Public Policy, 1(1):33-57.

MILLER, P. \& O'LEARY, T. 1987. Accounting and the construction of the governable person. Accounting, Organizations and Society, 12(3):235-265.

MITCHELL, R.K., AGLE, B.R. \& WOOD, D.J. 1997. Toward a theory of stakeholder identification and salience: Defining the principle of who and what really counts. Academy of Management Review, 22(4): 853-886.

NOHRIA, N. \& ECCLES, R.G. 1992. Networks and organizations. Boston: Harvard Business School Press. ORIN, R.M. 2008. Ethical guidance and constraint under the Sarbanes-Oxley Act of 2002. Journal of Accounting, Auditing \& Finance, 23(1):141-171.

OSBORN, R.N. \& HAGEDOORN, J. 1997. The institutionalization and evolutionary dynamics of interorganizational alliances and networks. Academy of Management Journal, 40(2):261-278.

OTLEY, D. \& FAKIOLAS, A. 2000. Reliance on accounting performance measures: Dead end or new beginning? Accounting, Organizations and Society, 25(4/5):497-510. 
OZER, M. \& ZHANG, W. 2015. The effects of geographic and network ties on exploitative and exploratory product innovation. Strategic Management Journal, 36(7):1105-1114.

POWELL, W.W. 1996. Trust-based forms of governance. In Kramer, R. \& Tyler, T. (eds.) Trust in organizations: Frontiers of theory and research. London: Sage:51-68.

PWC AUSTRALIA. 2013. Streamlined annual financial report. Australia: PWC Australia.

REITER, S. 1997. Storytelling and ethics in financial economics. Critical Perspectives on Accounting, 8(6):605-632.

ROSENFELD, S.A. 1996. Does cooperation enhance competitiveness? Assessing the impacts of inter-firm collaboration. Research Policy, 25(2):247-263.

ROTH, A.V. 1996. Achieving strategic agility through economies of knowledge. Strategy \& Leadership, 24(2):30-36.

RYAN, S.G. 2008. Accounting in and for the subprime crisis. Accounting Review, 83(6):1605-1638.

SAKO, M. 1992. Prices, quality, and trust: Inter-firm relations in Britain and Japan. Cambridge: Cambridge University Press.

SCHWEIKER, W. 1993. Accounting for ourselves: Accounting practice and the discourse of ethics. Accounting, Organizations and Society, 18(2/3):231-252.

SCOTT, J. 1991. Social network analysis: A handbook. Newbury Park, CA: Sage Publications.

SEAFORD, R. 2009. Money makes the (Greek) world go round: What the ancient Greek anxiety about money has to tell us about our own economic predicaments, Times Literary Supplement, 17 June:14-15.

SHEARER, T. 2002. Ethics and accountability: From the for-itself to the for-the-other. Accounting,

Organizations and Society, 27(6):541-573.

SUNDARAM, A. \& INKPEN, A. 2004. The corporate objective revisited. Organization Science, 15(3): 350-363.

TINKER, A.M., MERINO, B.D. \& NEIMARK, M.D. 1982. The normative origins of positive theories: Ideology and accounting thought. Accounting, Organizations and Society, 7(2):167-200.

TOMS, J. 2002. The rise of modern accounting and the fall of the public company: The Lancashire cotton mills 1870-1914. Accounting, Organizations and Society, 27(1/2):61-84.

TOYOTA ANNUAL REPORT. 2008.

VAGNEUR, K. \& PEIPERL, M. 2000. Reconsidering performance evaluative style. Accounting, Organizations and Society, 25(4/5):511-525.

WALL STREET JOURNAL. 2013. Cambodia factories grapple with issue of underage workers. Available at: http://www.wsj.com/articles/SB10001424052702303799404579287353595133592 [accessed 2015-03-11].

WILLIAMSON, O.E. 1985. The economic institutions of capitalism. New York: Free Press.

YOO, T. \& JHO, W. 2015. Socioeconomic contexts of government expenditure across OECD countries: A complementary perspective from trust and state-business relations. Administration \& Society, 47(2):122-150.

YOO, T. \& LEE, S. 2009. In search of social capital in state-activist capitalism: Elite networks in France and Korea. Organization Studies, 30(5):529-547.

YOUNG, J.J. 1996. Institutional thinking: The case of financial instruments. Accounting, Organization and Society, 21(5):487-512.

ZUKIN, S. \& DIMAGGIO, P. 1990. Structures of capital: The social organization of the economy. Cambridge, UK: Cambridge University Press. 